\title{
Effect of Kaatsu Training on Some Special Physical Variables and Performance of Some Motor Skills on Parallel Bars \\ *Dr/ Ashraf Haidar Aboul Fotouh
}

\section{Introduction and research problem}

The training process has made great strides towards progress in the modern era, and it is now obligatory for coaches to keep abreast of all the latest in the field of training to improve the training situation of their players.

Both Glass (2005) and Peter (2004) agree that skeletal muscles are severely affected by resistive training, and the apparent natural adaptation of muscles depends on the quality of the correlation and harmony of the variables.

Training at high intensity doses to muscle hypertrophy, improves performance. But this type of exercise may increase the level of physical load and muscle fatigue. Thus, it would be useful to develop safer and more effective methods to promote muscle hyperplasia without any adverse effects (37:13) (1465: 16.)

Both Takashi (2005) and Campos (2002) and Mc
Donagh (2002) agree that the amount of adaptation gained from training is proportional to the motivation and amount of effort exerted, and although it depends on individual training experience and level of fitness,

For example, training intensity exceeding $(65 \%)$ of the player's maximum capacity is the minimum acceptable that can have the positive effect we seek to increase muscle hypertrophy and achieve the required muscle strength $(100: 23)(55: 12)(155: 15)$

Many of the bodies involved in strength training have published benchmarks for optimal muscle development and increased strength as a general and general goal.

Most results agreed that exercise load intensity is less than $(65 \%)$ rarely increase in circumference and muscle mass and is considered high intensity of resistance exercises at a frequency. 3 times weekly is an important factor in

" Lecturer, Department of Gymnastics, Exercise and Sports Shows, Faculty of Physical Education, Arish University. 
increasing the level of growth hormone concentration which is the basis of muscle growth and strength (24:22)

Both Shunha (2002) and Takarada Takdan (2000) agree that exercises using venous blood flow restriction contribute significantly to increased muscle hypertrophy and increase the rate of muscle strength (77:19) $(84: 21$.)

Many scientists have agreed that a combination of low-intensity physical loads (20-50\%) in resistance training and restriction of venous blood flow (kaatsu exercises) to working muscles may be a more convenient alternative to achieving the goal of these exercises, more effectively than methods. Conventional methods are used to increase fusion and muscle size, but they may not be significantly influencing hormones such as high loads (12: 9)

Abe ", T" (2004) indicates that high intensity rates using kaatsu exercises for more than $80 \%$ require relatively long breaks between training units, according to the high load performed, mechanical pressure and maximum muscle damage. Low-intensity loads (50\%) do not affect (207: 10.)
Along with the effects of kaatsu training on muscle size and strength, it helps achieve metabolic adaptation in skeletal muscles. It represents metabolic responses to muscle nourishment (7). Muscles (138: 18.)

Resistance and strength exercises cause a high level of blood flow to the working muscles from the first muscle contraction, which depends on the persistence and high level of physical activity and recovery time (18:11.)

Artistic gymnastics is one of the most important sports that is characterized by the diversity and multiplicity of skills that lead to equipment and is one of the individual activities that contribute to the development and development of physical and skills, where the individual depends on his abilities in the completion of motor sentences. (4: 14) (5: 217)

Artistic gymnastics occupies a prominent place among the various colors of sports activity, because it is from sports loved to the self that attracts the attention of the viewer, although the exercise requires distinctive physical abilities and specifications, and artistic gymnastics is a distinctive color of physical 
activity, which is characterized by its comprehensive impact on the body's organs and organs, to ensure consistency and complementarity and contribute to improving the player's neuromuscular compatibility and physical, mental and social abilities to be a useful member of society. (6: 6)

Abdul Aziz Al-Nimr and Nariman Al-Khatib (2000) make it clear that artistic gymnasts must possess the physical qualities and capabilities that distinguish them from other individual sports.

Artistic gymnastics is characterized by difficulties in super-high technical performance and a challenge to the player's abilities, which requires a distinctive physical potential, especially The component of muscle strength, which is the most important physical character of the gymnast and its direct relationship to the level of technical performance $(7: 7)$

The development of the muscular strength of the upper limb of the body, especially the shoulder, chest, arms, abdominal muscles and grip strength, as well as the development of the muscular capacity of the muscles of the legs of the basic requirements in the physical preparation of the gymnast. (8: 498(

Amira Matar (2015) points out that the movements performed on the parallel device are strong, smooth and dynamic. He needs the muscles of the arms, shoulders, back and abdomen. (3: 104)

Adele Shenouda (2015) points out that muscular strength is considered one of the most important elements of physical fitness to affect the level of performance in gymnastics. Artistic gymnast has to act against resistance to body weight and is considered an important element in the development of other physical components. (2: 97)

The muscle strength of all three types of the most important physical elements of the parallel system so that the skills can be performed in the right form and differ in the distribution between parts of the body commensurate with the requirements of the skill. It also explained that flexibility and stretching play an important role in all joints of the body, especially the thighs and shoulders. 79)

The researcher noted that some trainers do not have the scientific knowledge of training exercises that help to 
develop muscle strength, which is the main and decisive factor in the development of muscle strength among artistic gymnasts and through training the researcher to the junior teams of artistic gymnastics the researcher noted the poor level of skill performance on the parallel device despite From the inclusion of weight training and muscle strength within the training program for young people to the maximum,

Which prompted the researcher to carry out this study to develop a new method that develops the level of muscle strength without an increase in training loads on young people; he conducted this study for exposure $\mathrm{P}$ on the impact of kaatsu exercises on some special physical variables and the performance of some motor skills on the parallel device.

\section{Research Goal:}

The research aims to identify the impact of kaatsu exercises on some special physical variables and perform some motor skills on the parallel device.

\section{Research hypotheses}

-There are statistically significant differences between the mean of the pre and post measurements in the level of some physical variables and the level of skill performance on the parallel system of the artistic gymnastics beginners of the experimental research group.

-There are statistically significant differences between the averages of the pre and post measurements in the level of some physical variables and the level of skill performance on the parallel device of the artistic gymnastics startups.

-There are statistically significant differences between the two mean measurements in the experimental and control groups in the level of some physical variables and the level of skill performance on the parallel apparatus of the artistic gymnastics beginners for the benefit of the experimental research group.

\section{Research plan and procedures \\ Research Methodology}

The researcher used the experimental method designed for the experimental and control groups to suit the nature of the research.

\section{The research sample}

The research sample included (20) beginners of artistic gymnastics in Ismailia in Ismailia Club, divided into two experimental and control groups, each consisting of (8) beginners and (4) beginners. 
Homogeneity of the research

Table (1)

sample:

The homogeneity of the research sample in the basic variables $n=20$

\begin{tabular}{|c|c|c|c|c|c|c|c|}
\hline $\mathbf{S}$ & Variables & Measurements & $\begin{array}{c}\text { measuring } \\
\text { unit }\end{array}$ & SMA & $\begin{array}{l}\text { Standard } \\
\text { deviation }\end{array}$ & Mediator & $\begin{array}{c}\text { Torsion } \\
\text { coefficient }\end{array}$ \\
\hline 1 & \multirow{4}{*}{$\begin{array}{l}\text { Growth } \\
\text { rates }\end{array}$} & Age & Year & 11.25 & .87 & 11.20 & 0.98 \\
\hline$r$ & & Height & $\mathrm{Cm}$ & 118.22 & 2.76 & 118.00 & 0.85 \\
\hline$r$ & & Weight & $\mathrm{Kg}$ & 31.88 & 1.89 & 31.50 & 0.43 \\
\hline$\varepsilon$ & & Training age & Year & 4.12 & 0.88 & 41.00 & 0.11 \\
\hline$\varepsilon$ & \multirow[t]{4}{*}{$\begin{array}{l}\text { Physical } \\
\text { variables }\end{array}$} & $\begin{array}{l}\text { Muscle } \\
\text { strength of the } \\
\text { arms }\end{array}$ & $\mathrm{Kg}$ & 38.52 & 1.90 & 38.50 & 0.65 \\
\hline 0 & & $\begin{array}{l}\text { Muscular } \\
\text { strength of the } \\
\text { legs }\end{array}$ & $\mathrm{Kg}$ & 67.82 & 2.88 & 67.80 & 0.43 \\
\hline 7 & & $\begin{array}{l}\text { Vertical jump } \\
\text { of stability }\end{array}$ & $\mathrm{Cm}$ & 28.12 & 1.56 & 28.00 & 0.44 \\
\hline $\mathrm{V}$ & & $\begin{array}{l}\text { Throw a } \\
\text { medical ball to } \\
\text { the farthest } \\
\text { distance }\end{array}$ & M & 8.13 & 0.98 & 8.00 & 0.33 \\
\hline \multirow[t]{5}{*}{9} & \multirow[t]{5}{*}{$\begin{array}{c}\text { Skill } \\
\text { variables }\end{array}$} & $\begin{array}{l}\text { Weighted front } \\
\text { and back }\end{array}$ & Degree & 2.11 & 0.12 & 2.10 & 0.25 \\
\hline & & $\begin{array}{l}\text { Stand on the } \\
\text { shoulders of } \\
\text { the } \\
\text { groundbreaking } \\
\text { sitting }\end{array}$ & Degree & 2.07 & 0.17 & 2.00 & 0.33 \\
\hline & & $\begin{array}{l}\text { The front } \\
\text { rolling of the } \\
\text { groundbreaking } \\
\text { sitting }\end{array}$ & Degree & 2.32 & 0.32 & 2.30 & 0.41 \\
\hline & & $\begin{array}{l}\text { Rear rolling of } \\
\text { groundbreaking } \\
\text { seating }\end{array}$ & Degree & 2.10 & 0.18 & 2.00 & 0.32 \\
\hline & & $\begin{array}{lr}\text { Landing } & \text { from } \\
\text { the } & \text { rear } \\
\text { weighted } & \end{array}$ & Degree & 2.55 & 0.10 & 2.50 & 0.18 \\
\hline
\end{tabular}

It is clear from Table (1) that the torsion coefficient of the research variables is confined between $( \pm 3)$ and located under the moderate curve, which indicates the homogeneity of the sample. 
Tools and means of data collection:

First: Devices and tools used in the research:

* Stopwatch $1 / 100$ of a second

* Boxes of different heights

*Ropes

* Medical balls with different weights

*Ristameter

* Dynamometer series

*Multi-use device

$*$ cones

*Hall equipped with tools

* Weights multiple weights.

*Parallel devices and mattresses.

* Multi gradient belts

II. Tests used in research: Annex 2

\section{(A): Physical tests:}

- Iron weight lifting test to measure the strength of the muscles of the arms.

-Dynamometer test to measure the strength of the muscles of the legs.

-Vertical jump test of stability to measure the muscle capacity of the two men.

-test throw a medical ball to the farthest distance to measure the muscle capacity of the arms.

(B) Evaluation of the skill level performance attached (2)

The researcher used the jury method to measure the skill level performance on the parallel device. This was done by three arbitrators from faculty members who obtained gymnastics arbitration certificates.

Third: Personal Forms and Interviews:

A questionnaire surveyed by the experts, whose names are attached (1) to determine the physical and skill tests under consideration. Attachment (3.r)(Registration form for each attached youth (4)

\section{Design of venous blood flow restriction:}

Blood pressure was measured from the forearm 15 minutes before the test. Exercise for each individual according to the arm and thigh circumference of each infant, a belt blood pressure was initiated on the arm and thigh (120) $\mathrm{mmHg}$ of systolic blood pressure. On the world Missed every two weeks (10) $\mathrm{mmHg}$ until he reached (170) $\mathrm{mmHg}$ at the end of the program.

Terms of Use of Kaatsu Belts Used in Research:

The rubber belts under consideration for pink blood flow exercises (KAATSU Air Bands) have been used, which 
are installed on the muscles working in the skill performance. The belts used are calibrated according to each program period and before starting the unit with a blood pressure indicator to ensure the safety of the belts used in the program. (36)

\section{Training program:}

The program was applied to volleyball players strongly ranging between (65 $85 \%$ ) of the maximum intensity of training for each item measured relative to the heart rate using the Polar watch, by repeating offensive strikes and different repetitions, and the rate of (3) intermittent breaks, both The two groups applied the same program and used external weights with the difference that the experimental group performed the restriction of venous blood flow,

While the control group performed the same exercises without restricting the venous blood flow, the training program was designed by (3) times a week and the performance in the exercises is consistent for both groups with varying intensity Fasten belts according For blood pressure and for 10 weeks connected to both groups.

\section{Preparation of the proposed training program: \\ Research Goal}

The proposed training program using kaatsu exercises (pink blood flow) to improve some of the physical variables and skill level performance of the artistic gymnastics beginners to parallel.

\section{Foundations of the proposed program:}

1-The training program should be commensurate with the objectives set.

2-Appropriateness of the program and its contents from exercises for the dental stage of the selected sample.

3-Program flexibility and adaptability.

4-Taking into account the training principles of the program (warm-up - main part - conclusion)

5-Pregnancy cycle formation (1: 1)

Presentation and discussion of the results

Table (2) 
The significance of differences between pre and post measurement in the level of some physical and skill variables Artistic gymnastics beginners have an experimental research group $N=8$

\begin{tabular}{|c|c|c|c|c|c|c|c|c|c|c|}
\hline \multirow{2}{*}{\multicolumn{2}{|c|}{ Variables }} & \multirow{2}{*}{$\begin{array}{l}\text { Measuri } \\
\text { ng unit }\end{array}$} & \multicolumn{2}{|c|}{ Pre measuring } & \multicolumn{2}{|c|}{ Post measuring } & \multirow{2}{*}{$\begin{array}{c}\text { Differences } \\
\text { between the } \\
\text { two averages }\end{array}$} & \multirow{2}{*}{$\begin{array}{c}\text { Rate of } \\
\text { improvement }\end{array}$} & \multirow{2}{*}{$\begin{array}{c}\text { Calculated }(v) \\
\text { value }\end{array}$} & \multirow{2}{*}{$\begin{array}{c}\text { Significanc } \\
\text { e level }\end{array}$} \\
\hline & & & M & $\mathbf{E}$ & M & $\mathbf{E}$ & & & & \\
\hline \multirow{4}{*}{$\begin{array}{l}\text { Physical } \\
\text { variables }\end{array}$} & $\begin{array}{l}\text { Muscle strength of } \\
\text { the arms }\end{array}$ & $\overline{\mathrm{Kg}}$ & $\overline{38.11}$ & 0.18 & 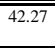 & $\overline{0.27}$ & 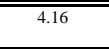 & 10.91 & 4.18 & Indicated \\
\hline & $\begin{array}{l}\text { Muscular strength } \\
\text { of the legs }\end{array}$ & $\mathrm{Kg}$ & 66.65 & 0.29 & 71.35 & 0.21 & 4.70 & 7.05 & 4.22 & Indicated \\
\hline & $\begin{array}{l}\text { Vertical jump of } \\
\text { stability }\end{array}$ & $\mathrm{Cm}$ & 27.90 & 0.54 & 31.25 & 0.65 & 3.35 & 12.00 & 4.12 & Indicated \\
\hline & $\begin{array}{l}\text { Throw a medical } \\
\text { ball to the farthest } \\
\text { distance }\end{array}$ & $\mathrm{M}$ & 8.10 & 0.27 & 8.87 & 0.11 & 0.77 & 9.50 & 4.71 & Indicated \\
\hline \multirow{5}{*}{$\begin{array}{c}\text { Skill } \\
\text { variables }\end{array}$} & $\begin{array}{ll}\begin{array}{l}\text { Weighted } \\
\text { and back }\end{array} & \text { front } \\
\end{array}$ & Degree & 2.09 & 0.51 & 4.10 & 0.28 & 2.01 & $49.02 \%$ & 4.85 & Indicated \\
\hline & $\begin{array}{l}\text { Stand on the } \\
\text { shoulders of the } \\
\text { groundbreaking } \\
\text { sitting }\end{array}$ & Degree & 2.05 & 0.22 & 4.22 & 0.21 & 2.17 & $51.42 \%$ & 4.65 & Indicated \\
\hline & $\begin{array}{l}\text { The front rolling } \\
\text { of the } \\
\text { groundbreaking } \\
\text { sitting }\end{array}$ & Degree & 2.12 & 0.17 & 4.15 & 0.17 & 2.03 & $48.91 \%$ & 4.28 & Indicated \\
\hline & $\begin{array}{l}\text { Rear rolling of } \\
\text { groundbreaking } \\
\text { seating }\end{array}$ & Degree & 2.06 & 0.36 & 4.11 & 0.36 & 2.05 & $49.87 \%$ & 4.69 & Indicated \\
\hline & $\begin{array}{l}\text { Landing from the } \\
\text { rear weighted }\end{array}$ & Degree & 2.10 & 0.21 & 4.36 & $\begin{array}{c}0.01 \\
0\end{array}$ & 2.26 & $51.83 \%$ & 4.22 & Indicated \\
\hline
\end{tabular}

(T) tabular value at the significance level $(0.05)=2.131$

It is clear from Table (2) that there are statistically significant differences between the averages of pre and post measurements in the level of some physical and skill variables among the artistic gymnastics beginners experimental research group and the researcher attributed this improvement to the proposed training program using kaatsu exercises.

The researcher believes that training restricting venous blood flow makes statistically significant differences as an indicator to increase the rate of blood flow in the muscles, and the subsequent increase of the circumference of the muscles of the thigh and arm as well as increased muscle mass, muscle strength,

While the same exercises without restricting blood flow and muscle packaging did not give the same results were observed for the control group in the variables under consideration, which can be considered that the exercises Kaatsu cause of muscle growth and strength, which is consistent with the study "Takashi" Gnakin (2006) 23 (23) Yasuda (2008) (24) on the effectiveness of Kaatsu exercises in Improve muscle strength.

The results of some studies indicate that lowintensity workouts improve muscle strength, while the 
same workouts with the same intensity without restraining the muscles cause an improvement in the level of muscle strength as the strength of the muscles of the legs improved with exercises.

The researcher attributes these results to the increase in the area of transverse muscle fibers. Therefore, the change in the mass and circumference of the skeletal muscles observed in the present study is a direct result of the increase in muscle enlargement and strength, which was confirmed in the study of Ayman Fekry (2006). Radwa Elsharkawy, (2015) (17.)

Mc Donagh (2002) 15 agrees that the temperature caused by partial vascular obstruction leads to a decrease in the amount of oxygen, which increases blood flow in skeletal muscles. Oxidation stimulates blood vessels to secrete muscle growth factor (VEGF) and secretion of fibroblast growth factor (FGF), these two factors are most influential in the growth of veins and muscle fibers, which lead to increased muscle strength, and muscle enlargement.

The increase in muscle size is explained by the effect of training by restricting venous blood flow, as the performance of many aerobic training modules significantly stimulates the muscles of the body, although the wrestler was expected to get tired more quickly during restriction of blood flow, which did not happen as in units High intensity and fast performance,

To illustrate this idea has recorded the increased electrical excitement of the muscles that work restricting venous blood flow compared to the same exercises without restricting blood flow has been achieved in this study that the intensity through which the program was synchronized with the restriction of blood flow Venous affect positively on the increase of the groin and arm circumference and increase muscle strength and ability. (22) (19)

Thus, the first hypothesis was made, which states that there are statistically significant differences between the mean of the pre- and postmeasurements in the level of some physical variables and the level of skill performance on the parallel device of the artistic gymnastics beginners 
Table (3)

The significance of differences between pre and post measurement in the level of some physical and skill variables Artistic gymnastics creators have a control group $N=8$

\begin{tabular}{|c|c|c|c|c|c|c|c|c|c|c|}
\hline \multirow{2}{*}{ Variables } & & \multirow{2}{*}{$\begin{array}{c}\text { Measuring } \\
\text { unit }\end{array}$} & \multicolumn{2}{|c|}{$\begin{array}{c}\text { Pre } \\
\text { measuring }\end{array}$} & \multicolumn{2}{|c|}{$\begin{array}{c}\text { Post } \\
\text { measuring }\end{array}$} & \multirow{2}{*}{$\begin{array}{l}\text { Differences } \\
\text { between } \\
\text { the two } \\
\text { averages }\end{array}$} & \multirow{2}{*}{$\begin{array}{c}\text { Rate of } \\
\text { improvement }\end{array}$} & \multirow{2}{*}{$\begin{array}{l}\text { Calculated } \\
\text { (v) value }\end{array}$} & \multirow{2}{*}{$\begin{array}{c}\text { Significance } \\
\text { level }\end{array}$} \\
\hline & & & M & $\mathrm{E}$ & M & $\mathrm{E}$ & & & & \\
\hline \multirow{4}{*}{$\begin{array}{l}\text { Physical } \\
\text { variables }\end{array}$} & $\begin{array}{l}\text { Muscle strength } \\
\text { of the arms }\end{array}$ & $\mathrm{Kg}$ & 38.16 & 0.20 & 40.10 & 0.87 & 1.94 & 5.08 & 3.64 & Indicated \\
\hline & $\begin{array}{l}\text { Muscular } \\
\text { strength of the } \\
\text { legs }\end{array}$ & $\mathrm{Kg}$ & 66.70 & 0.27 & 68.90 & 0.27 & 2.20 & 3.29 & 3.87 & Indicated \\
\hline & $\begin{array}{l}\text { Vertical jump } \\
\text { of stability }\end{array}$ & $\mathrm{Cm}$ & 27.96 & 0.23 & 29.10 & 0.19 & 1.14 & 4.07 & 3.90 & Indicated \\
\hline & $\begin{array}{l}\text { Throw a } \\
\text { medical ball to } \\
\text { the farthest } \\
\text { distance }\end{array}$ & $\mathrm{M}$ & 8.12 & 0.19 & 8.44 & 0.65 & 0.32 & 3.94 & 3.98 & Indicated \\
\hline \multirow{5}{*}{$\begin{array}{l}\text { Skill } \\
\text { variables }\end{array}$} & $\begin{array}{l}\text { Weighted front } \\
\text { and back }\end{array}$ & Degree & 2.10 & 0.18 & 3.12 & 0.12 & 1.02 & $32.69 \%$ & 3.29 & Indicated \\
\hline & $\begin{array}{l}\text { Stand on the } \\
\text { shoulders of the } \\
\text { groundbreaking } \\
\text { sitting }\end{array}$ & Degree & 2.06 & 0.32 & 3.10 & 0.21 & 1.04 & $33.54 \%$ & 3.24 & Indicated \\
\hline & $\begin{array}{l}\text { The front } \\
\text { rolling of the } \\
\text { groundbreaking } \\
\text { sitting }\end{array}$ & Degree & 2.11 & 0.28 & 3.21 & 0.36 & 1.10 & $34.26 \%$ & 3.56 & Indicated \\
\hline & $\begin{array}{l}\text { Rear rolling of } \\
\text { groundbreaking } \\
\text { seating }\end{array}$ & Degree & 2.09 & 0.31 & 3.18 & 0.21 & 1.09 & $34.27 \%$ & 3.22 & Indicated \\
\hline & $\begin{array}{lr}\text { Landing } & \text { from } \\
\text { the } & \text { rear } \\
\text { weighted } & \\
\end{array}$ & Degree & 2.11 & 0.11 & 3.55 & 0.18 & 1.44 & $40.56 \%$ & 3.27 & Indicated \\
\hline
\end{tabular}

(T) tabular value at the significance level $(0.05)=2.131$

It is clear from Table (3) that there are statistically significant differences between the mean of pre and post measurements in the level of some of the physical and skill variables of the artistic gymnastics beginners of the control group. The researcher attributed this improvement to the traditional training program used with the young of the control group.

Adil Saad (2015) points out that the special motor skills in gymnastics are not easy skills, but it takes a long time to master and to train based on sound scientific grounds, especially considering the transition of the player around the axis of his body on the ground or other devices and modern legal amendments, And increasing the cycle of difficulties. (28: 2)

Adel Abdul Basir (2004) mentions the artistic gymnastics is one of the most important sports that is 
characterized by the diversity and multiplicity of skills that lead to equipment and is one of the individual activities that contribute to the development and development of physical and skills, where the individual depends on his abilities in the completion of motor sentences. (67: 6)
Thus, the second hypothesis was made, which states that there are statistically significant differences between the mean of pre and post measurements in the level of some physical variables and the level of skill performance on the parallel device of the artistic gymnastics startups.

Table (4)

The significance of the differences between the two remote scales in the level of some physical and skill variables Volleyball two experimental and control search groups $N 1=n 2=8$

\begin{tabular}{|c|c|c|c|c|c|c|c|c|}
\hline & \multirow[t]{2}{*}{ Variables } & \multirow{2}{*}{$\begin{array}{c}\text { Measuring } \\
\text { unit }\end{array}$} & \multicolumn{2}{|c|}{$\begin{array}{c}\text { Experimental } \\
\text { group }\end{array}$} & \multicolumn{2}{|c|}{$\begin{array}{c}\text { Control } \\
\text { group }\end{array}$} & \multirow{2}{*}{$\begin{array}{c}\text { Calculate } \\
\text { d (v) } \\
\text { value }\end{array}$} & \multirow{2}{*}{$\begin{array}{c}\text { Significance } \\
\text { level }\end{array}$} \\
\hline & & & $\mathrm{M}$ & $E$ & $\mathrm{M}$ & $\mathrm{E}$ & & \\
\hline \multirow{4}{*}{$\begin{array}{l}\text { Physical } \\
\text { variables }\end{array}$} & $\begin{array}{l}\text { Muscle strength of } \\
\text { the arms }\end{array}$ & $\mathrm{Kg}$ & 42.27 & 0.27 & 40.10 & 0.87 & 2.74 & Indicated \\
\hline & $\begin{array}{l}\text { Muscular strength } \\
\text { of the legs }\end{array}$ & $\mathrm{Kg}$ & 71.35 & 0.21 & 68.90 & 0.27 & 2.82 & Indicated \\
\hline & $\begin{array}{l}\text { Vertical jump of } \\
\text { stability }\end{array}$ & $\mathrm{Cm}$ & 31.25 & 0.65 & 29.10 & 0.19 & 2.28 & Indicated \\
\hline & $\begin{array}{l}\text { Throw a medical ball to } \\
\text { the farthest distance }\end{array}$ & M & 8.87 & 0.11 & 8.44 & 0.65 & 2.29 & Indicated \\
\hline \multirow{5}{*}{$\begin{array}{l}\text { Skill } \\
\text { Variables }\end{array}$} & $\begin{array}{l}\text { Weighted front } \\
\text { and back }\end{array}$ & Degree & 4.10 & 0.28 & 3.12 & 0.12 & 2.33 & Indicated \\
\hline & $\begin{array}{l}\text { Stand on the shoulders of } \\
\text { the groundbreaking } \\
\text { sitting }\end{array}$ & Degree & 4.22 & 0.21 & 3.10 & 0.21 & 2.54 & Indicated \\
\hline & $\begin{array}{l}\text { The front rolling of the } \\
\text { groundbreaking sitting }\end{array}$ & Degree & 4.15 & 0.17 & 3.21 & 0.36 & 2.85 & Indicated \\
\hline & $\begin{array}{l}\text { Rear rolling of } \\
\text { groundbreaking seating }\end{array}$ & Degree & 4.11 & 0.36 & 3.18 & 0.21 & 2.65 & Indicated \\
\hline & $\begin{array}{l}\text { Landing from the } \\
\text { rear weighted }\end{array}$ & Degree & 4.36 & 0.010 & 3.55 & 0.18 & 2.47 & Indicated \\
\hline
\end{tabular}

*Tabular value $(\mathrm{T})$ at the significance level $(0.05)=1.725$

It is clear from Table (4) that there are statistically significant differences between the mean measurements of the dimensional measurements of the artistic gymnastics beginners on the parallel device experimental and control groups in the level of some physical and skill variables and for the benefit of the experimental research group. This improvement is due to the proposed training program using Kaatsu exercises.

The results of the current study indicate that the kaatsu exercises make statistically significant differences in the 
increase of the upper and lower extremities accompanied by increased muscle strength,

While exercises without restricting blood flow do not make those differences statistically significant (for the control group), which in turn affected the rest of the variables Especially for the experimental group, which was supported by increased blood supply of working muscles and also helped in regularity of breathing and delaying access to fatigue (24.)

Both Fujita and Peter (2004) 16 suggest that both low-intensity and highintensity workouts restricting venous blood flow increase the size and mass of skeletal muscles more than only highintensity resistance exercises, since it is assumed that exercise-restricted exercise Blood will stimulate muscle protein synthesis more than just strength training.

It is clear from the results of previous studies that exercises with high intensity with restriction of venous blood flow better than training with low intensity with restriction of venous blood flow on increased muscle hypertrophy, and confirms a direct correlation between the occurrence of phosphorylation (S6K1) in the first hours after training High intensity and improvement in muscle mass after several weeks of high intensity training in humans (31) (11)

Training that increases and enlarges skeletal muscle, which is described as the maximum peak of the strength and velocity development curve, is defined as the percentage of the peak of the power curve, which depends on the age and duration of the training unit and ultimately leads to the adaptation of the required exercise (14) (17)

Strength training (1RM) is the most influential factor in training modules and on neurological responses in general, which can be felt after (10) training modules (17), where the exercises of strength and resistance are the most influential on the body components and skeletal muscle growth in adult men (35)

The researcher believes that the relationship between the basic skills in artistic gymnastics and its different 
physical requirements (general, private) is a close relationship that must be taken into account when preparing junior, and that there is no separation between the two skills and physical numbers, on the contrary, the development of physical elements in accordance With the skill requirements it is a success in the training process and thus upgrade the level of players when the player possesses high physical qualities can perform all the skills well.

Physical component is one of the pillars of training that depends on the development of the player and is an important basis that is associated with the motor skills in the formation of the player from a physical point of view, therefore, the physical components are the most important performance requirements in the sport of artistic gymnastics,

Which may be the deciding factor in achieving the best skill performance Especially when the skill level of the competitors is equal or convergence, because the level of physical condition of young people is one of the important reasons that contribute to achieve many victories, the high level of fitness for the young enables him to perform a successful sports season in addition to the high The physical fitness of the player increases the confidence of the coach in his player and even the coach often tries to benefit from and maintain it.

Thus, the third hypothesis has been achieved, which states that there are statistically significant differences between the two mean measurements in the experimental and control groups in the level of some physical variables and the skill performance level on the parallel system of the artistic gymnastics youth.

\section{Conclusions:}

* Resistance training exercises help increase muscle strength in artistic gymnastics beginners.

* Resistive kaatsu exercises help improve motor skills on a parallel device for artistic gymnastics beginners.

\section{Recommendations:}

-The use of kaatsu exercises because of their importance in improving the physical 
qualities of artistic gymnastics beginners.

-The application of kaatsu exercises to improve the biological and physical qualities that help improve motor skills in artistic gymnastics.

-Awareness of volleyball coaches on the effectiveness of the use of kaatsu exercises because of its positive impact on increasing muscle strength among young gymnastics.

-It is preferable to apply exercises using rubber band and belts in the morning according to the program used and its results as well as in the light of the results of previous studies.

-The need to calibrate the rubber belt used every two weeks due to the change (tensile strength) and so as not to affect the effectiveness of the exercises used due to the opinion of experts and previous studies.

\section{References}

\section{1-Abdul Aziz Al-Nimr,}

Nariman Al-Khatib: Physical preparation and weight training for young people in the prepuberty stage, professors of sports book, Cairo, 2000.
2- Abe T, Yasuda Midorikawa $\mathbf{T}$ T, Sato $Y$, Kearns CF, Inoue $\mathbf{K}$, Koizumi $\mathrm{K}$, and Ishii $\mathrm{N}$ : Skeletal muscle size and circulating IGF-1 are increased after two weeks of twice daily Kaatsu resistance training. Int $\mathbf{J}$ KAATSU Training Res 1: 612, (2005).

3- Abe, T: Effects of short term low intensity Kaatsu training on strength and skeletal muscle size in young men (Japanese with English abstract). J Training SciExerc Sport 16: 199-207,(2004).

-4 Adel Abdul Basir Ali: Artistic Gymnastics (boys and girls), the Egyptian Library for Printing and Publishing 2004.

\section{5-Adeel Saad Shenouda,} Samia Farghaly Mansour: Artistic Gymnastics, Concepts and Applications, Forum of Thought, Alexandria, 1999.

\section{6- Adeel Saad Shenouda and} others: Artistic gymnastics concepts and applications, I 2 Forum thought, Alexandria, 2015.

\section{7- Amera Matar and others:} Artistic gymnastics and its applications in the light of scientific innovations, 2nd floor, Helwan University, Cairo, 2015. 
8- Aymanfekry: Relation between prostaglandin changes as an indicator for blood flow at muscles during high intensity effort, research not published for master degree, faculty of physical education for boys, Helwan University, (2006)

9-Campos GER, Luecke TJ, Wendeln HK, Toma $K$, Hagerman FC, Murray TF, Ragg KE, Ratamess NA, Kraemer WJ, and Staron RS: Muscular adaptation in response to three different resistance-training regimens: specificity of repetition maximum training zones. Eur $\mathbf{J}$ ApplPhysiol 88: 50-60, (2002). 10- Glass DJ. Skeletal muscle hypertrophy and atrophy signaling pathways. Int $\mathbf{J}$ Biochem Cell Biol 37, (2005).

\section{1- Kraemer wj. Ratamess}

NA: Fundamentals of resistance training progression and exercise prescription. Med Sci Sports Exerc 36: 674-688, (2004).

\section{2- McDonagh MJ and} Davies CT: Adaptive response of mammalian skeletal muscle to exercise with high loads. Eur J ApplPhysiol 52: 139-155, (2002).
13-Mohamed Mahmoud Abdel Dayem, Medhat Saleh Sayed, Mohammed Shukri al-Qutab (2001): training programs for physical numbers and weight training, Al-Ahram Press Corniche El-Nile, Cairo, 2001.

14-Peter H. Connolly, Vincent J. Caiozzo, FrankZaldivar, Dan Nemet, Jennifer Larson, She-pin Hung, J. Denis Heck, G. Wesley Hatfield, Dan M. Cooper: Effects of exercise on gene expression in human peripheral blood mononuclear cells, Journal of Applied Physiology Published 1 October 2004Vol. 97no. 14611469 DOI:

$10.1152 /$ japplphysiol.00316, (2004).

\section{5- Radwa Soliman}

Elsharkawy, Maysa Mohamed Rabia Effect of training program with restricted venous blood flow "KAATSU"' on skeletal muscle (mass and size), strength, Prostaglandins (PGE2) and $400 \mathrm{~m}$ sprinting records, International Journal of Sports Science Faculty of Physical Education for Boys Kir Alexandria

16- Rowell LB, Freund PR, and Hobbs SF: Cardiovascular 
responses to muscle ischemia in humans' ApplPhysiol,Circ Res 48: 137-147,( 2009).

17-Salwa Roshdy and others: systematic gymnastics, Helwan University, Cairo, 2010.

18- Shinohara M, Kouzaki M, Yoshihisa $\mathrm{T}$ and Fukunaga $\mathrm{T}$ : Efficacy of tourniquet ischemia for strength training with low resistance. Eur J Applied Physiology OccupPhysiol 77, (1998).

19-Stephen D. Patterson, Richard. A. Ferguson: Increase in calf post-occlusive blood flow and strength following short-term resistance exercise training with blood flow restriction in young women, European Journal of Applied Physiology, March 2010, Volume 108, Issue 5, pp 1025-1033,(2010).

20-Takarada Y, Takazawa $H$, Sato Y, Takenoshita S, Tanaka $\mathbf{Y}$, and Ishii $\mathbf{N}$. Effects of resistance exercise combined with moderate vascular occlusion on muscular function in humans. J Appl Physiol 88: 2097-2106, (2009).
21- Takarada Y, Sato Y, and Ishii N: Effects of resistance exercise combined with vascular occlusion on muscle function in athletes. Eur J ApplPhysiol 86: 308-314, (2002).

\section{2- Takashi Abe1, Charles F.} Kearns1, and Yoshiaki Sato: Muscle size and strength are increased following walk training with restricted venous blood flow from the leg muscle, Kaatsu-walk training, Journal of Applied Physiology vol. 100 no. 5 1460-1466 Article,10.1152/japplphysiol.0 1267.2005,1 May (2006).

23-Talha Hossam El-Din: The Dynamics and Functional Foundations of Sports Training, Dar Al-Fikr AlArabi, Cairo, 1994.

24-Yasuda T, Abe T, Sato Y, Midorikawa $\mathbf{T}$, Kearns CF, Inoue $\mathrm{K}$, Ryushi T, and Ishii N: Muscle fiber cross-sectional area is increased after two weeks of twice daily Kaatsuresistance training. Int J Kaatsu Training Res 1: 65-70, (2008). 